東南アジア 一歴史と文化一 №.26,1997

（3）比島調査委員会編『比島調查報告書』（全 2 巻）（中野聡- 早瀬晋三・寺田勇文・永 野善子解説）（南方軍政関係史料(11)，龍渓書舎，1994年）

（4）日本のフィリピン占領期に関する史料調査フォーラム編『インタビュー記録 日本 フィリピン占領』（龍渓書舎，1994年）

（5）たとえば，75-76頁の村田大使暗殺計画の箇所.

（6）藤原帰一「帝国主義論と戦後世界」『岩波講座 近代日本と植民地 1 ：植民地帝国日 本』（1992年，岩波書店）第11章, pp.267-268.

Eiji Murashima (Worasakd Mahatthanobol: Plae lae Bannathikan)

$$
\begin{aligned}
& \text { Kanmuang Jin Sayam: } \\
& \text { Kan Khluangwai thang Kanmuang khong } \\
& \text { Chaw Jin Phon Thale nai Prathet Thai } \\
& \text { Kho. So. 1924-1941 (夕イ文) }
\end{aligned}
$$

Sun Jin Sukusa Sathaban Eshia Sukusa Culalongkorn Mahawithayalai, Krungthep, 1996, xxviii + 写真17.pp.+237.pp., 220バーツ

村嶋英治 著・訳 ：ウォラサック・マハッタノーボン 共訳・編集

シャム華人の政治：タイ国における華僑の政治運動 1924年-1941年

チュラーロンコーン大学アジア研究所中国研究センター, バンコク, 1996年

\title{
宮田 敏之
}

I

タイ王国と中華人民共和国の国交樹立20周年を記念して，1995年 7 月 1 日タイ国チ ュラーロンコーン大学アジア研究所に中国研究センターが設立された。同センターは, 両国の共同研究，セミナー開催，文献収集など幅広い活動を展開中である。本書は， 著者によるおよそ20年の夕イ政治研究の一端が, 同センター最初の研究書として1996 年 2 月バンコクで発刊されたものである。特に1980年代初頭以降10数年にわたってタ イ, 日本, 英国, 米国の公文書館・国立図書館等で著者が地道に収集した夕イ語, 中 国語, 日本語, 英語の一次資料をもとに丹念にまとめあげられており, 同センター初 の刊行物にふさわしい質と量を兼ね備えた労作である。出版まもない1996年 3 月には 
チュラーロンコーン大学で本書に関するセミナーが開かれ，4 月 1 日と 8 日付の日刊 タイ字紙『プー・ジャットガーン (経営者)』には, タマサート大学政治学部のカシア ン [Kasian Tejapira] 博士が書評を寄せるなど, 夕イ国内で高い関心を呼んでいる。 本書は, タイで共産主義派とシャム国民党総支部との対立が鮮明となる1924年から 1941年日本軍が夕イに侵攻する直前までのシャム華僑の政治活動を詳細に記述分析し たものである。本書の特筆すべき点は，以下の 4 点に整理できよう。第一に，これま で本格的に検証されていない夕イ語, 中国語, 日本語, 英語の一次資料を駆使し, か つインタヴューもまじえて，従来のシャム華僑政治研究の水準を実証的に大きく引き 上げた点にある。例えば, 本書32ぺージの指摘にもあるように, これまでシャム華僑 研究の代表作とされたスキンナー [G.W. Skinner 1957：237] では, 日中戦争勃発 前のシャム華僑が政治的に統一されていた，と記述するのみであった。確かに，スキ ンナーの研究では, 華字紙の党派性は指摘されてはいたが, 本書で展開されているよ うに華字紙の内容に立ち入ってシャム国民党とシャム共産党との対立, シャム国民党 内部の主導権争いを分析しょうとしているわけではない。著者は, 党派性が強く前面 に押し出されていた1939年までの華字紙『華暹新報』(蕭佛成派), 『華僑日報』(陳守 明・反蕭佛成), 『謜青（LI SAE）日報』（共産党系）等々をそれぞれを丹念に読み込 むことによって，シャム華僑内のこうした政治的対立構造を実証的に明らかにしてい る。第二に, 従来の研究史の空白とも言える1930年代半ば以降のシャム共産党の活動 それ自体を明らかにしている点である。つまり，華校を舞台にした活動，抗連の結成， 抗日団体を統制するために共産党系の抗連が国民党系華抗や青抗らとともにすすめた 救国総連盟の組織化などを明らかにした点である。先行研究, 例えば, 1927年から1958 年までの夕イ共産主義の形成を分析したタマサート大学のカシアンの業績においても, 1935年一1941年までの共産主義運動は最も資料が不足し不明瞭であるとし, 比較的裕 福な華僑の子弟達による急進的運動を紹介するにとどまっていたのである [Kasian Tejapira $1992: 112-116]$ 。第三に，シャム華僑要人個々の政治活動に関する分析を 積み上げながら，シャム華僑の政治活動の動静を描こうとしている点である。つまり， 党派レベルのみならず, 個人のレベルでその経歴やシャムおよび中国での政治活動が 具体的に描かれており, シャム華僑の政治活動の複雑さや生々しさが伝わってくる。 これには, 『泰国帰僑英魂録(1)〜 (3)』な゙の中国語資料の活用やインタビューが大きく 貢献していると言えよう。例えば，シャム華僑の政治活動の高まりとして取り上げら れている数回にわたる日貨ボイコット, 国民党と共産党派にわかれての抗日救国活動, 共産党派・青抗・紅字（アンジー）などの制裁やテロなどの分析はその好例であろう。 
その当事者たる蕭佛成, 陳守明, 蟻光炎, 馬立群, 張蘭臣など国民党派の大物はもち ろんの事, 共産党派の劉漱石, 李華, 青抗の劉茂雲など, これまで紹介される事の少 なかった重要人物にも目配りが行き届いている。第四に, 当時の日本・英国の外交文 書・各種報告を駆使して, 在シャム日本公使・イギリス公使のシャムとの交涉, シャ ム華僑に対する認識を明らかにしている点である。特に, シャム華僑の政治運動の展 開が結局「抗日」運動を軸にしていた事を考えあわせると，そのターゲットとなった 日本の対応・認識が外交史料によってその内側から分析されたことは重要である。さ らにそれが夕イ語で紹介されたことは夕イの学界に大きな成果をもたらしたと言える。 例えば，1941年当時シャム華僑の重慶政府離れや抗日運動の後退を過大に評価し, 日 本側のシャム華僑の政治活動に対する認識が実態とかなりズレを生じ, 実情の適確な 分析を時として欠いていた点を指摘しているところなど興味深い(本書190ページから 194ページ)。

なお，本書の底本である日本語版は，村嶋英治「タイ華僑の政治活動- $5 \cdot 30$ 運動 から日中戦争まで一」(原不二夫編著『東南アジア華僑と中国』アジア経済研究所, 1993 年所収）として発表されている。本書（夕イ語版）は，この日本語版で割愛された資 料の補充および加筆を行い, 筆者自身がまず口頭で翻訳をおこない, チュラーロンコ ーン大学中国研究センターのウォラサック・マハッタノーボン研究員が修正・編集し た。ただし, 最終校正および, 巻末に付された詳細な夕イ語・中国語対照りスト作成 は，村嶋氏自身がおこなった。その後，タマサート大学政治学部ナッカリン・メーク トライラット準教授によるタイ語の点検をへて出版された。こうして作成されたタイ 語版は日本語版に比べ本文だけでもおよそ35パーセント増補され, さらには21名の華 僑要人の写真, 詳細な夕イ語・中国語対照リストが付され, 内容に一層厚みが増して いる。

\section{II}

\section{$2 \cdot 1$ 構成}

序文 (アジア研究所所長ウィッタヤー・スッチャリッタナーラック)

序文 (中国研究センター長アムポン・パンチェート)

讃辞（チュラーロンコーン大学政治学部キアン・ティーラウィト教授）

謝辞 (村嶋), 著者・共訳者解説（村嶋・ウォラサック）

編集者序説（ウォラサック）

著者序章 (村嶋) 
写真

第一章 シャム国民党の政治活動

1 ・シャム国民党総支部と蕭佛成派

2 ・ シャム国民党の蔣介石派（中央派）と西南派

3 ・「潮州会館派」と陳守明の抗日救国活動

第二章 シャム共産党派の政治活動

1 ・ シャム共産党派の政治活動：シャム共産党時代

2 ・「抗連」の抗日救国運動

第三章 華人夕イ人化強制政策と華人の対応

第四章 結語

引用文献

夕イ語中国語人名対照表

タイ文字表記による中国人名・組織団体名

\section{$2 \cdot 2$ 要旨}

第一章 シャム国民党の政治活動（p. 1-p.73）

1 ・シャム国民党総支部と蕭佛成派

1920年代半ばから1931年までを対象に，当時国民党シャム総支部長であった蕭佛成， 国民党派内の反蕭佛成派，さらには蕭佛成に対立し第二支部を設立した共産党の動向 を分析している。シャム政府内部の公文書，イギリス公使からシャム政府への外交文 書などや, 蕭佛成派の華字紙『華暹新報』, タイ字紙『チノサヤーム・ワラサップ』, 反蕭佛成派の華字紙『華僑日報』『中華報』, 共産党系の華字紙『勵青 (LISAE) 日報』 などの華字紙・タイ字紙に依拠し, 主として次の 3 点に焦点をあてている。まず, 日 中関係, 中国における国民党・共産党の関係の変化がシャム華僑の政治運動に与えた 影響である。特に，1925年 5 ・30事件，1928年済南事件，1931年満州事変後のシャム における反日運動・日貨ボイコットの実態や，シャム華僑内の党派対立を詳細に描い ている。第二に, 中国の影響を受けたシャム華僑の動きに対する在シャムのイギリス 公使, 日本公使の抗議およびシャム政府のこれに距離をおいた対応と1929年以降の厳 しい取り締まりへの変化を明らかにしている。第三に，シャム政府に対する恭順を示 す一方で中国の反英運動・日貨ボイコットを支持し，他方で自らの頭越しになされる 中国国民党とシャム政府の交渉に強く反発する蕭佛成のしたたかな行動を追っている。 この時期を代表するシャム華僑・蕭佛成の政治的に微妙なバランスの取り方を公文書 
東南アジア 一歴史と文化一 N No.26,1997

や華字紙から浮かびあがらせている。

2 ・シャム国民党の蔣介石派（中央派）と西南派

1931年から1936年までを対象としている。まず，満州事変後西南政務委員会として 統合されたが1936年まで独立状態を維持した西南派（汪兆銘の旧広東国民政府）と蔣 介石の南京政府（中央派）との中国における対立が，シャムにも分裂状況を生み出し た点を明らかにしている。1932年からシャム中華総商会主席と中華民国の駐シャム商 務委員（Trade Commissioner）を兼ねた陳守明派（中央派・蔣介石派・商専派）と蕭 佛成の流れを汲み蟻光炎を中心とする西南派（後の潮州会館派）の分裂である。また， 立憲革命後の 1932 年義務教育法制定以降1935年の華校閉校に至る人民党政府の夕イ語 教育強制策，華僑の政治活動取り締まりの強化に焦点をあてている。

3 ・「潮州会館派」と陳守明の抗日救国活動

本節では，1936年から1940年代初頭までのシャム国民党派の 2 派，西南派の系譜を 持つ蟻光炎らの「潮州会館派」と陳守明派の抗日救国運動を各派の華字紙などに依拠 して紹介している。両派ともに1937年日中戦争勃発以後抗日救国運動を進めたが，中 国国民党は無論のこと中国共産党をも支援していた点を強調している。蟻光炎は1936 年陳守明に代わり中華総商会主席となり，1939年暗殺されるまでこの任を務め，1938 年には潮州会館を陳景川らとともに結成した。「潮州会館派」の抗日救国活動は, 勧募 公債シャム分会を通じた募捐活動 (救国公債の販売・送金・募金), 救郷 (夕イ米輸 送)，回国服務（中国に渡り軍人・技師などとして救国活動），回国投資である。これ に対し陳守明は，自派の華字紙，タイ字紙で抗日救国を盛んに宣伝し，中国において は夕イ華僑代表として国民参政会の参政員に，さらに戦時公債勧募委員に任じられた。 また，重慶政府の求めに応じて西南（雲南・四川）への開発回国投資に協力した。当 時の圧倒的多数の華僑は国民党を支持し進んで献金した。同時に日貨ボイコットの裏 で日本人商人との取引きを理由に共産党派や愛国集団の脅迫・暴力的制裁の標的にな った者（余子亮ら）も多い。

第二章 シャム共産党派の政治活動（p.74-p.165）

1 ・シャム共産党派の政治活動：シャム共産党時代

第二章は，タイ字紙，華字紙，シャム共産党のビラ・冊子，華僑要人の回想録・イ ンタビューをもとに，筆者が最も紙数を割いて詳細に分析した本書の核心でもある。 本節は1920年代半ばから1937年の抗連結成までを対象とし，この間の共産主義活動の 広がりとこれに対するシャム政府（立憲革命前後）の取り締まりを実証的に分析して 
いる。本節で最も特筆すべきは, 国立公文書館所蔵の各種ビラ・冊子を駆使して, シ ヤ厶共産党が立憲革命・人民党政府を「帝国主義勢力の手先」（1932年 7 月 9 日）「偽 の革命家」(1932年 9 月30日)として厳しく批判した点を, 詳細に分析しているところ にある。ルアン・プラディット（プリーディー・パノムヨン）も同様に「圧政者」の 一人として（同 9 月30日）批判の対象とされている。これは，共産党が立憲革命に参 加したとし，ルアン・プラディットの思想とシャム共産党の活動を混同してきた従来 の見解を実証的に批判する重要な指摘である。これ以外の重要な論点は次の 5 点であ る。まず，第一に，1924年に共産党派が第二支部を結成するが，1922年にはすでに譚 振三が華字紙『僑聲（KEW SING）報』を創刊し共産党派が一定の広がりを持ってい た点。第二に，1927年中国における共産主義弾圧により，後にリーダーとなる劉漱石， 伍冶之, 李華など多数の共産主義者がシャムへ入国し, その多くは華校の教師, 労働 者となっていた点。第三に, こうした共産主義浸透に対し, ラーマ7 世王は絶対主義 の危機と捉え深く憂慮していた点。第四に，1930年シャム内務省が作成した 9 件の共 産主義者取締事件によれば，バンコクはもとより南部のサムイ島から北部ウッタラデ イット県まで広く浸透していた点。特に1934年の記録にもあるようにバンコク・東北 地方などで活発であったべトナム人の活動も丹念に実証している。第五に，1936年半 ば以降, タイ字紙・華字紙のシャム共産党記事が激減し, 度重なる逮捕・国外追放に よって党組織が弱体化した点, を指摘した。

2 ・「抗連」の抗日救国運動

1937年から1939年までを対象とし，抗連を中心としたシャム共産党の抗日活動の再 編を検証している。前半は『泰国帰僑英魂録 $(1)$ 』泰国㷌僑英魂録 $(2$ )』などに掲 載されている回想録を用いて, 内戦停止と抗日救国のために組織されたシャム華僑各 界抗日救国連合会（抗連）の活動, 幹部の経歴などを紹介している。抗連は, 文化界

(文抗) 工業（工抗）商業（商抗）婦女（婦抗）学生（学抗）・地区センターなど, 幅 広く組織化された。主たる活動内容は, 募金, 新四軍や八路軍への物資援助, 蟻光炎 の援助を受けた回国服務, 及び抗日ボイコットであった。日本品を扱う華僑奸商への 制裁は, 商抗や, 特に新たに結成された鋤奸団・紅字 (アンジー) があたり, 謝罪文・ 送金を要求し，これに従わない場合暴力的制裁に訴えた。1937年後半には綿布類を除 く全商品が取引停止となった。1938年抗連幹部の大量逮捕追放の後もテロは収束せず, 暴力制裁の統制にあたるため救国総連盟が作られた。欧陽恵の回想録, 青抗の幹部で あった劉茂雲らへのインタビューにもとづいて, 9 団体一抗連（婦抗，学抗，工抗）, 国民党 (華抗), 青抗, 青抗少年先鋒隊, 青抗婦人部, 熱抗, 鉄血青年抗日会一からな 
る救国総連盟の活動を紹介している。特に, 劉茂雲等によれば, 青抗は制裁の実行部 隊を有していたが，もともと愛国心により自発的に結成されたものであり，腐敗した 熱抗などとは異なっていたようである。1939年には青抗指導者が逮捕され，多くは回 国服務にあたったため，活動は低下したが，制裁・脅迫は横行し，やがて華僑商人の 中では政経分離の主張が表面化しはじめた。

第三章＼cjkstart華僑タイ人化強制政策と華僑の対応（p.166-p.207）

本章は，1938年以降の華僑タイ人化強制政策や経済ナショナリズムの進展とこれに 対する華僑の対応に焦点をあて，1941年日本の侵略に対抗するために制定された「志 願兵」募集までを検討している。筆者によれば，1935年から1939年までは，華字紙が 部数を増大させ, 華校での教育も発展し, 日中戦争の勃発によって抗日救国運動など 華僑ナショナリズム（Chatniyom khong Chau Jin Phon Thale）が最も活発化した 時期であったとされる。他方, シャム政府側では1938年末のピブーン政権成立を待つ までもなく， 7 月のルアン・ウィチット無任所大臣の華僑批判に象徵されるように華 僑取締が強化されていた。1939年には華抗の大量逮捕，『中原報』以外の華字紙の出版 禁止, 全華校の閉校が実施された。華校の学生は昆明などに逃れる者も多数でた。ナ コンラーチャシーマーなどでだされた 90 日以内の市中心部からの退去命令によっても， 華僑約 1 万人が強制移住させられ, 特に貧困層は厳しい生活を強いられた。また, 華 僑の日貨ボイコットを契機に1938年12月にはシャム（タイ）ライスカンパニーが設立 され, 経済ナショナリズムも強引に推し進められた。しかし，ピブンは華僑のタイ化 を重視しており，1939年11月にはピブン首相が内務省に華僑にタイ籍を与える政策の 促進を指示し,「華僑がタイ社会に忠誠を持ち, 実際上何よりもまずタイ人であるとい うアイデンティティを示すことを望んでいた」のである。

こうしたシャム政府の政策のもとで，華僑は政治面での中国人としての活動は国外 追放の対象とされ，経済的にも政府の介入を受け，華僑の過激派からの対日経済断交 や献金を要求され, 時にテロの対象となるという幾重もの困難に直面していた。筆者 によれば，華僑の対応は次の 3 つに分類される。第一は，タイ人化政策に応じてタイ 人になりきろうとする対応である。タイ国籍の獲得申請をした移民第一世代の華僑な どが多いが，中華総商会主席もつとめた馬立群（Ma Bulakun）などはその代表であ る。第二は, 中国人としての政治活動を貫く立場である。その結果国外追放になった 黄有鸞や共産党派の華僑などがこれに含まれよう。第三は, 夕イの国法を遵守し, 政 経分離に基づき日本との商取引も行うが，祖国の戦いも支援するという対応である。 
多くの華僑指導者がとった立場である。本文では，日本側資料による華僑の蔣介石政 府離れの記述が詳細に紹介されているが，結局，陳守明らによる憲法記念日，空軍， インドシナ国境交渉などへの寄付・資金援助と余子亮などに見られた積極的抗日支援 の同時存在こそが，この立場の特徵を良く示している。

第四章＼cjkstart結語（p.208-p.215）

最後に, 全体の要約と本書の研究史上の意義をまとめている。特に, 過去のシャム の華僑問題が，単なるマイノリティの問題ではなく，その政治意識の高さとそれに基 づく政治運動がタイ人にも大きな影響を与えた点でタイ政治研究においてその重要性 が極めて大きかったにもかかわらず，研究史上の空白であった点を再度確認している。

\section{III}

以上のように, 戦間期のシャム華僑の国民党・共産党・愛国団体の対立と連携, 抗 日組織の結成とその活動など，これまでにない知見が豊富に紹介されている。シャム 華僑政治研究史, 戦間期夕イ政治・経済研究の空白を埋める意味で, 著者の試みはか なりの成功をおさめたと考える。そこで最後に, タイ学界での反応, 評者の夕イ経済 史研究からのコメントを整理して本書評を締めくくりたい。

まず，第一に，タイにおける反響の一端を紹介しておく。冒頭で紹介した日刊タイ 字紙『プー・ジャットガーン (経営者)』1996年 4 月 8 日付けの書評におけるタマサー ト大学のカシアンの主たる批判は, ピブン政権下のタイ人化政策と華僑の 3 つの対応 （本書185ページから196ページ）に関するものであった。つまり著者の 3 つの分類で は，夕イ政府に敵対しかつ文化的には中国人性（タイ語のクワーム・ペン・チン）を 持ち続ける華僑，すなわちシャム共産党の立場が抜け落ちてしまうというものである。 確かに，本書の華僑の対応に関する分類は多分に国民党派の華僑を念頭においている かのような誤解を生じやすい。しかし，著者の分類はピブンの強制的夕イ人化政策に 対する政治的対応のレベルのもので，そこに中国語を依然として話すかどうかなどと いった文化的要素は初めから想定されていないようである。よって，カシアンの批判 は華僑の政治的対応と文化的要素を一度に論じようとした点で逆に読者に混乱を与え ている。ただし，カシアンが近年強調している「チン・サヤーム」の議論は，積極的 に評価されて良いだろう。「チン・サヤーム」自体は一般にタイ語で言うところのコン タイ・チュアサーイチン（文字どおりは中国系タイ人）に相当するもので，タイで生 まれ，夕イ語で教育を受けてはいるが，家庭内や家のまわりの中国的文化・雾囲気も 
肌で感じて育った人々・世代をさす。カシアン自身もこの世代である。こうした議論 は結局, 中国系の人々に存在する世代の相違を強調するものである。逆に，本書は世 代の相違にあまり力点をおいていないようである。すなわち，シャム在住の歴史に大 きな違いが見られるシャム国民党派とシャム共産党派も, 同じ「華僑・華人」として 論じられている。本書で紹介されている要人の内, 国民党派は蟻光炎が 1 世であるが その他ほとんどは 2 世，3 世である。他方，1930年代に活躍した共産党派の主力メン バー劉漱石，李華などは，1920年代後半以降シャムに来た 1 世である。「チン・サヤー ム」という用語を使用するかどうかは別にして，こうした「世代」を視野に入れた政 治活動の研究は今後ますます重要になると考える。

第二に，本書181から182ページのタイ（当初はシャム）ライスカンパニー設立の背 景に関し，当時の世界的米需給と外貨獲得からコメントしておきたい。設立の主たる 背景・要因は本書でも強調されているように華僑の抗日ボイコットを契機としたピブ ーン政権の経済ナショナリズムの高揚である。さらに，本書では華僑の抗日ボイコッ 卜に対して商業局の代替策が不十分で，タイ農民が打撃を受け，タイ経済全体も苦境 に陥った点, また, 当時の経済大臣ボリパンュッタキットの葬式本を引用して, 日本 にタイ米を供給できないことが日本軍に侵略の口実を与えるのではないか，という対 日警戒観が当時の夕イ政府指導者に存在していたこと, を指摘している。前者は抗日 ボイコットがタイ国内の政治経済社会状況に与えた影響, 後者は政府の外交スタンス とタイライスカンパニー設立を結び付けたものである。しかしながら，設立の背景は 夕イ国内外の政治経済状況やピブーン政権の国内・対外政策からより広く捉える必要 があると考える。当時の国際環境を考えた場合，少なくとも次の 2 点は重要であろう。 第一に欧洲に抢ける戦争勃発や1937年の世界的な米不作による米需給の逼迫であり， 第二に夕イ政府にとっての外貨獲得拡大の重要性である。特に, 後者は, 戦時中に出 された杉山清の報告［杉山清 1945］にもあるように，当時夕イバーツがポンドとリ ンクし，イングランド銀行の預金がバーツの発行準備となっていた点と密接な関係が ある。つまり，タイライスカンパニーの輸出拡大は，外貨（ポンド）獲得につながり， 結局イングランド銀行にあるタイのポンド預金増加をもたらし，その預金とリンクし たバーツ発行そのものにも跳ね返るというものである。よって, タイライスカンパニ 一の設立は，国際政治経済状況が緊迫を増していた1930年末において，タイ経済の対 外的自立性を支える一つの重要な政策であったという側面も考慮する必要があると考 えられる。

第三に，潮州会館派と陳守明派との対立の中味についてである。例えば，手もとに 
ある泰国潮州会館「泰國潮州会館五十年会務紀要：公元1932年 2 月-1988年 2 月」『泰 國潮州会館成立五十周年紀念特刊』1989年（1ページ：以下「会務紀要」）および1994 年にアンポンが執筆した蟻光炎の伝記 [Amphon 1994：102]によれば, 陳守明は1936 年潮州会館発起人の 55 名に含まれており，そこから推挙された準備委員 7 名にも名前 を連ねている。この意味では末廣昭氏が陳守明を潮州会館の広い意味での Founder と するのも妥当であろう [Suehiro 1989：121-122]。ただし，本書 (41ページ) で指摘 のとおり1938年の会館設立時には陳景川を主席とする幹部役員には陳守明の名前があ がっておらず (「会務紀要」1ページ，32ページにも同様の記載), むしろ陳守明派と 潮州会館派は対立関係を強めていた。以上の点から，本書が第一章で強調している両 者の対立にまつわつて次のような疑問が生じるであろう。つまり, 潮州会館設立準備 期と設立以後の両者の関係にどのような変化があったのか？ 或は陳守明の発起人・ 準備委員就任の意味をどのように考えればよいのか？ という点である。要するに， 陳守明の潮州会館設立準備委員就任と本書が強調した潮州会館派と陳守明派との対立 とが一見矛盾する動きとして捉えられるのである。評者は現在こうした矛盾を説明し 得る具体的な材料に乏しいが，本書で実証的に示されたシャム華僑・華人内の政治的 党派的対立とともに，婚姻・ビジネスなど社会・経済関係に結び付けて華僑・華人間 の諸関係を総合的に分析する作業こそ必要ではないかと考えている。

第四に，抗連・青抗がバンコクの奸商に対しておこなった警告と制裁，とりわけ香 港や重慶の銀行口座への罰金振り込みを指示していた点（128ページ，134ページ） な どは経済史的にも大変興味深い。確かに抗日救国活動の目的が中国の支援にあった以 上中国への物資輸送・送金ルートが構築されたのは容易に理解できる。しかし，罰金 の振り込み確認さえもが, 銀行振込証明で斉むという信用制度の一般的な広がりとそ の確立はより注目されてよいと考える。つまり，シャム華僑のナショナリズムの展開 が，シャム・香港・中国にまたがるグローバルな経済ネットワークを前提にしていた と考えられるからである。華僑銀行や批館などを通じた日常的なアジア内の金融シス テム・貿易決済システムの存在なしには，抗日救国活動そのものの実効性も薄れたで あろう。逆にこうした政治活動こそがシャムと香港・中国との経済的な結びつきを強 化したとも言えよう。いずれにせよ, 従前の如くシャム国内のボイコットや暴力的制 裁だけに焦点をあてるのではなく，本書がシャム・香港・中国にまたがる抗日救国活 動を明らかにし，中でも罰金やその清算方法を具体的に示した点は, 戦間期のアジア 間貿易や金融ネットワーク研究に対しても重要な示唆を与えるものであった。

今回の夕イ語版は, 著者の夕イ人研究者との幅広い研究交流と夕イ語, 中国語, 日 
本語，英語史料への真摰な対峙から生まれた。その意義は単に夕イ語で書かれたとい うだけにとどまらず，タイに研究成果を問い返す試みとして高く評価されるべきであ ろう。特に日本語史料を通じて日本側の見た夕イをも紹介し, 双方の資料を総合した 点で, 日本・タイの研究交流の進展に大きな足跡を残したと言えよう。

\section{参考文献}

*Amphon Iamsuri, Rak Chat Ying Chip : Chiw Prawati Hia Kwong Iam（己を捨て国を 愛す：蟻光炎の伝記), Hang Hun Suan Jam Kat Midia Press, Krungthep, 1994.

${ }^{*}$ G. W. Skinner, Chinese Society in Thailand : An Analytical History, Cornell University Press, Ithaca, 1957.

*Akira Suehiro, Capital Accumulation in Thailand: 1855-1985, The Center for East Asian Cultural Studies, Tokyo, 1989.

*Kasian Tejapira, "Commodifying Marxism: The Formation of Modern Thai Radical Culture, 1927-1958," Unpublished Ph. D. dissertation, Cornell University, Ithaca, 1992. *Kasian Tejapira, Lelot Lai Mangkon: Ruam Khokhian wa duay Khwam Pen Jin nai Sayam (龍画を通して：シャムにおける中国人性に関する覚書), Khrong Kan Jat Phim Khop Fai, Krungthep, 1994.

*杉山清『泰國経済の分析』日本評論社 1945年 